\title{
Response to “A Student's Right to Freedom of Education”
}

\author{
Mikayla Benner \\ Ambrose University, Canada
}

\begin{abstract}
Dr. Eugene Matusov's article "A Student's Right to Freedom of Education," promotes a system of education which is vastly different from how education has been generally approached for the past century. Matusov writes that freedom in education is an integral part to what education means (Matusov, SF3). This is my response to his article.
\end{abstract}

Mikayla Benner is a student at Ambrose University, Canada

\section{eds}

Dr. Eugene Matusov's article "A Student's Right to Freedom of Education," promotes a system of education which is vastly different from how education has been generally approached for the past century. Matusov writes that freedom in education is an integral part to what education means (Matusov, SF3). From my understanding, this means that freedom must be a part of education or it ceases to be education entirely. I disagree with this definition. I do not believe education must be defined by the student, but neither do I believe that it must be defined by the state or by the teacher. I think that education is a system which is used for learning. There can be many forms of education. Not all students learn the same way and we should try to help students learn in a way that suits them best. Education is about learning and learning well. Matusov seems to care more about the process than the product. He does not argue his case for educational freedom because it will "pragmatically improve educational outcomes," but rather because he believes that freedom is intrinsic to education (SF3). This view focuses on education as a right. Because it is our right, we should be allowed to do what we want within it. But with every right comes a responsibility. We cannot ignore our responsibilities simply because we have the right to do something. We have the right to free speech, but we also have the responsibility to use our words carefully and not speak hatefully towards people.

In the same way, I do believe that education is a right that all people deserve, but I also believe that education is a responsibility. For the citizens of Canada (my own country), they have the responsibility to be educated to a particular level in order that they can be good capable citizens able to give back to the country they belong to. This does not mean I believe that everyone needs to go to university or even graduate from High School. But it does mean, that for those who are able, they need to learn to read and do basic math, if only for the purpose that they can function in our society. There are some things that we must learn even if we do not want to.

On the positive side, I see the value of freedom and being able to pursue the topics and subjects that each student chooses. Being invested in a topic and taking responsibility of their learning improves the student's experience. They will learn better, retain more, and enjoy the process. An example of this is Matusov's "Curricular Map," which I think is a brilliant idea. It allows the students agency in their learning but still relies on the intellect and mastery of the teacher. By providing a wide variety of topics that fit within the scope of a larger topic, students are able to focus on what they would enjoy learning while still 
completing the requirements of a course. Unfortunately, this would not work for some courses, especially those which are cumulative learning, where each new topic is built off of the knowledge of the previous one. It also becomes more difficult the larger the class size, since it is less likely that students will come to a consensus about what they want to learn. But the courses that can accommodate this structure should.

However, even in these freer circumstances, I believe that there should be teacher involvement. Not just to guide the learning along productive paths, but also to motivate and correct the student when they make mistakes. Freedom of education is a wonderful thing, but I do not believe it can be done in excess. Some freedom is good, but freedom in education without guidance, without correction, and without an external challenging influence will not lead to a positive outcome.

It is essential to have a teacher. Whether that teacher is a person, a book, or in some cases experience, it does not matter; there is always a teacher. Experiential learning is limited to tangible education. If a student ever desires to learn other subjects they will need to rely on people or books, which not coincidentally are written by people. Matusov's attempt to remove the teacher from the equation, unless the student chooses, is a faulty one. It cannot be done in any meaningful way. Rather, he should argue that students should be able to choose their teacher because learning is rarely done in complete isolation. To deny the need for a teacher entirely is a mistake. For example, it has taken centuries for the world to make the discoveries that are a part of our everyday life. Each of those inventors built on the knowledge of their predecessors. They did not start from scratch. They learned from someone. In the same we have all learned from teachers, parents, books, and peers.

Matusov writes an inflammatory sentence claiming that conventional classrooms often punish students for mistakes (SF12). It is not clear exactly what he means by punished. If he means degraded and made fun of, I will admit, that does happen on occasion, but that is not a fault of the system, but of the teacher. If, on the other hand, he means corrected and shown how to fix their mistake, then by all means keep on "punishing" the students. Correction is an essential tool for learning.

It is true that in some subjects there is no "right" answer. There are often many opinions pertaining to a single subject and the teacher should not present their own view as the only view. Similarly, the teacher should not find fault in a different opinion simply because it is different. However, there are subjects whose answers are non-negotiable. Two plus two will always equal four, and any other answer is incorrect. Without correction in a student's life, they could falsely believe in success when in actuality they are failing to learn. While Matusov does briefly address this possibility of poor learning, he does not acknowledge that there is an issue (SF12). How can failure to learn constitute education, let alone good education? Learning through mistakes is extremely valuable, but how will we know that they are mistakes unless someone tells us? I do not want to live in a world where no one is ever wrong or where we are not allowed to tell someone they are wrong. Being wrong allows us to grow in a way that being right never will.

Matusov's freedom in education requires and exorbitant amount of internal motivation. While some might possess such a trait, very few do. Children, especially, if there is not someone telling them to study or practice, will not do it. Instead, they will play. Play is extremely valuable and can be educational. But that is not the point here, the point is that children will veer towards what is easy and what is fun. While learning can be fun, it is not often easy. It requires hard work and practice. This does not apply just to children; it applies to adults as well. How much better do we work when there is someone beside us and encouraging us? But, in the system that Matusov proposes, the teacher is supposed to stand back and wait for the student to come to them, and if they never come, that is alright. Under this system, how is the teacher able to provide the fundamental support of encouragement and pushing the student to do more than they think 
they are capable of? Matusov writes against this objection concluding that children may choose to play when they are young but will later choose learning and that adults see the value in learning. While this may be true, the desire to learn is only the first step to actually learning. Even once desire is present, people still need encouragement and external motivation to accomplish their goal.

My argument surrounding the lack of motivation to learn is not without proof. In fact, the best proof comes from the continuing COVID-19 crisis. In Canada, students find themselves learning from home online. The grades they had before the crisis are not allowed to decrease, just in case a student has particular difficulty learning at home for any reason, be it situational or technological. The teachers, however, provide their classes with optional work which can be accessed and completed online. The hours the students would need to work in order to complete all their tasks would take significantly less time than they would attend school. For example, in Alberta, an elementary school teacher is only allowed to give their students five hours of schoolwork a week. Although the work is lessened, the teachers are completely available to provide support or more work should a student desire it. COVID-19 has provided us an opportunity to view a part of freedom in education. The students are able to choose whether or not they want to do school. It is completely up to them. Teachers have found that many students do not do their work at all. The students have chosen to do anything but school. Because there are no consequences with a failure to complete work, such as a lowering of grades, students do not bother to do work at all. This is not limited to young children. Many universities gave students the option to take their grade or receive credit for a course, meaning all they needed to do was pass the course. In no way would it affect their GPA. Presented with these options, many students failed to finish work, or simply did substandard work because they knew there would be no repercussions.

Foisted education, as Matusov calls it, is forcing a student to learn a particular subject or even forcing a student to learn in a particular way. Opposing Matusov's view, I believe that there is a strong place for foisted education. I have had plenty of foisted education in my life, and although I did not enjoy it at the time, I can see the value of what I learned now. As a young person I strongly disliked formal writing. It did not help that I was not very good at it. But I was forced to write essays throughout high school and university. Over the years I have improved significantly, and I no longer dread writing papers. But, without being forced to write and without the feedback from my teachers, which I did not always like to read, I would not be as capable as I am now. Many students might avoid particular subjects that are actually very important. Simply because one does not enjoy something does not mean that it ceases to be valuable or important for, they themselves to learn.

Similarly, my university professor Dr. Dyck asked our class to be technology free. We were not to use our laptops for taking notes, and if we had questions, he asked us to meet him in person rather than emailing him. I wanted to write on a different topic than the ones he had suggested for the novel we were reading. In any other class I would have emailed my professor because I found that easier than talking in person. However, I was forced to speak with Dr. Dyck face to face. Despite my apprehension, I found that my meeting was far more fruitful than any email could have been. I was able to have a meaningful discussion about the book we were reading in class, which I would not have gotten through an email. We talked through the strengths and weaknesses of my argument and he was able to give me a new perspective on the book. I was forced to step outside of my comfort zone because of the classroom rules, and I found it extremely beneficial.

I do not believe that freedom is integral to education, but it can be positive. Freedom can encourage creativity and investment. But there is more to education than the process. The product is extremely important otherwise we would not have driving tests, instead we would allow everyone to drive at a certain 
age regardless of competency. I believe firmly in the value of teachers and in the encouragement and correction they give us.

\section{(cc) EY}

New articles in this journal are licensed under a Creative Commons Attribution 4.0 United States License.

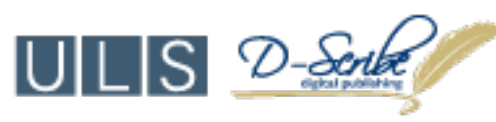

This journal is published by the University Library System, University of Pittsburgh as part of its D-Scribe Digital Publishing Program and is cosponsored by the University of Pittsburgh Press. 